in educators of preschool institutions, for development of musical abilities of children of 4-7 years, according to structure of this phenomenon, reflecting author's model representations about its maintenance and features, was developed.

Based on the definition of the essence of "readiness of educators of preschool institutions for the development of musical abilities in children 4-7 years old" concept, its components were characterized. The value-motivational component is assessed using the motivational-axiological criterion, cognitive component - by operational-semantic criterion, activity component - by activity-reflective criterion. The defined criteria are characterized by indicators: motivational-axiological criterion - by value attitude to the future pedagogical activity, interest in mastering the forms, methods and techniques of the development of musical abilities in children aged 4-7 years; the need to succeed in professional activities; operational and semantic criterion - by consistency, efficiency; activity-reflection criterion by the formation of skills and abilities to develop musical abilities in children aged 4-7 years; educator's self-assessment of the formed readiness for this type of activity.

The author differentiated the readiness levels of educators for the development of musical abilities in children aged 4-7 years, on the basis of the traditional three-level gradation (high, medium, low). Based on the analysis, the author revealed the content essence of the readiness of educators of preschool institutions for the development of musical abilities in children aged 4-7 years, the components of readiness were determined, and the criteria, indicators and levels of formation of the denoted readiness were substantiated.

Key words: training, readiness, educator, development of musical abilities, children aged 4-7 years, criterion, indicator, level of formation.

Дата надходження статті: 17.10.2020 p. Рецензент: доктор педагогічних наук, професор Жерновникова О.А.

УДК [378.091.2.013:341](44)

DOI https://doi.org/10.37915/pa.vi46.127

Писаревська О. В., orcid.org/0000-0001-5166-1464

\title{
МОДЕЯЬ ФОРМУВАННЯ СТРАТЕГІЧНОЇ КОМПЕТЕНТНОСТІ МАЙБУТНІХ ЮРИСТІВ-МІЖНАРОДНИКІВ В УНІВЕРСИТЕТАХ ФРАНЦІЇ
}

У статті проаналізовано актуальні підходи до моделювання як методу дослідження педагогічних процесів і явищ, що дозволяе виявити їх основні компоненти та описати взаємозв'язок і умови функціонування. Розглянуто поняття стратегічної компетентності майбутнього ториста-міжнародника, яку в межах нашого дослідження розуміємо як складну, диналічну, інтегративну систему особистісних якостей та професійно-значущих знань, умінь $і$ навичок, спрямованих на адекватний $і$ ефективний вибір стратегій $i$ тактик у професійній діяльності, щзо набувають студенти під час професійного навчання. У статті представлено результати дослідження процесу формування стратегічної компетентності правників на прикладі навчання юристів-міжнародників в університетах Франції у вигляді авторської моделі формування зазначеної компетентності. Результати аналізу науковопедагогічних джерел та нормативних документів дозволили визначити п'ять основних взаємопов'язаних блоків розробленої моделі: цзільовий - містить соціальне замовлення суспільства, мету та завдання формування стратегічної компетентності; методологічний включае ї̈ компоненти (змістовий, професійно-когнітивний, діяльнісно-оперативний, комунікативно-інформаційний та особистісно-мотиваційний) та основні принциии і підходи

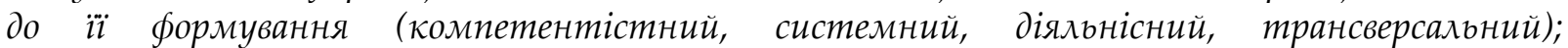

“(C) Писаревська О.В.

U3 193 
організаційно-процесуальний, що містить форми, методи, засоби формування аналізованої компетентності; змістовий - зміст дисциплін, навчальних курсів, знання, вміння, навички; контрольно-результативний - критерії, показники та рівні сформованості стратегічної компетентності майбутніх юристів-міжнародників під час їх професійної підготовки в університетах Франції.

Ключові слова: стратегічна компетентність, моделювання, модель, міжнародне право, вищца освіта Франц̧ї.

Постановка проблеми. Аналізуючи проблему формування стратегічної компетентності, iї сутність та компоненти, здійснимо спробу моделювання згаданого феномена у контексті предметної галузі «Міжнародне право» в університетах Франції. Основним завданням університету є підготовка висококваліфікованого фахівця, який є конкурентоздатним на ринку праці. Сучасне суспільство висуває вимоги до такого фахівця, створюючи соціальне замовлення, що відображається в нормативних та законодавчих документах (стандарт, рамки квадіфікацій, освітні програми). Однак якісна підготовка фахівців зі спеціальності «Міжнародне право» в українських закладах вищої освіти немождива без грунтовного аналізу досвіду закордонних, зокрема європейських університетів. Тому наша дослідницька увага була зосереджена на реалізації моделі освітнього процесу на юридичних факультетах Франції, аналізі та обгрунтуванні складових педагогічної моделі формування стратегічної компетентності майбутніх юристів-міжнародників та взаємодії цих складових.

Аналіз досліджень. Професійна підготовка спеціалістів у галузі міжнародного права, як в українських, так і у французьких університетах базуються в першу чергу на компетентністному підході, вивченню якого присвячені праці закордонних та українських дослідників, зокрема Ф. Вайнерта, Г. ле Бофера, Ж. Бутена та Д. Жюльєна, О. Пометун, А. Хуторського тощо. Питання професійних якостей фахівців міжнародного права у різних країнах та особливості професійної комунікації у цій сфері досліджували В. Третько, Ю. Шатило, Ю. Михайліченко, Н. Ничкало,

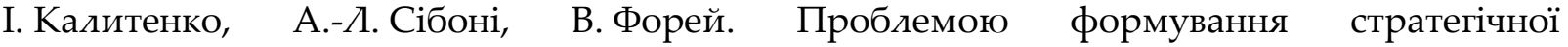
компетентності у майбутніх фахівців різних спеціальностей цікавляться О. Шапран, М. Оліяр, К. Пасинчук. Однак, ефективної моделі формування стратегічної компетентності юристів-міжнародників досі створено не було.

Метою статті е конструювання моделі формування стратегічної компетентності майбутніх юристів-міжнародників в університетах Франції та обгрунтування iï компонентів.

Виклад основного матеріалу. В нашому дослідженні ми розглядаємо модель формування стратегічної компетентності майбутніх юристів-міжнародників як науково обгрунтований проєкт реалізації системи педагогічних умов, методів, змістових та організаційних складових компетентісно-орієнтованого процесу професійної підготовки фахівця у галузі міжнародного права в університетах Франції. На сучасному етапі розвитку науки метод моделювання застосовується у багатьох галузях. Інтеграція моделі в експериментальний метод забезпечує іï міцний зв'язок 3 реальністю. Використання формул або абстрактних фігур, головним чином математичних, для представдення природних або техногенних явищ та об'єктів постійно супроводжує розвиток науки та техніки. Інші наукові дисципліни та галузі діяльності, зокрема, науки про життя та соціальні науки, також використовують інструменти модедювання. Побудова моделі вимагає визначення сфер ії валідності. На думку К. Шмідт-Дени та А.Пави, модель має тимчасовий статус і їі можна змінювати та вдосконалювати, тоді як закон встановдюеться на довгострокову перспективу. Мистецтво будувати і використовувати моделі, потім співвідносити та кодифікувати результи спостереження та експериментів, поклало початок практичному моделюванню. Така практика перетворилася в реальну методологію. На переконання дослідників, модель - це перш

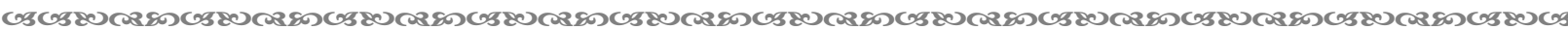
194 
за все інструмент у процесі засвоєння знань. Вона повинна мати сенс, iї компоненти повинні бути зрозумілими [12, с. 29].

Модель (від франц. module, від лат. modulus - зображення) - це схема, графік будьякого об'єкта, процесу або явища, що використовується як його спрощена заміна, створювані 3 метою одержання і (чи) збереження інформації; специфічний об'єкт у формі уявного образу, опису знаковими засобами (формули, графіки) або матеріального предмета, що відбиває властивості, характеристики і зв'язки об'єкта-оригіналу довільної природи, істотні для задачі, розв'язуваної суб'єктом (дюдиною) [5, с. 109]. У свою чергу моделювання - це дослідження будь-яких явищ, процесів або систем об'єктів шияхом побудови та вивчення їх моделей; використання моделей для визначення або уточнення їх характеристик та раціоналізації побудови об’єктів, що знову конструюються; дослідження об’єктів пізнання на їхніх моделях, побудова, аналіз і вивчення моделей об'єктів [там само, с. 110].

За С. Гончаренком, це допоміжний засіб, який у процесі пізнання, дослідження дає нову інформацію про основний об'єкт вивчення [2, с. 120]. С. Базидь вважає, що педагогічна модель показує взаємозв' язок між елементами досліджуваного процесу і їхню залежність один від одного, а також надае мождивість з'ясувати й виокремити важливі характеристики аналізованого об'єкта і його функціонування [1, с. 77]. За визначенням М. Фіцули, моделювання спрямоване на створення і дослідження наукових моделей - смислово представленої і матеріально реалізованої системи, яка адекватно відображає предмет дослідження і є засобом теоретичного дослідження педагогічних явищ через уявне створення моделювання) життєвих ситуацій; допомагає пізнати закономірність поведінки дюдини у різних ситуаціях» [6, с. 30]. На основі аналізу педагогічних умов та попередньо проведених досліджень нами була розроблена модель формування стратегічної компетентності майбутніх юристів-міжнародників в університетах Франції. Усі компоненти розробленої моделі є взаємопов'язаними та взаємодоповнюючими, їх взаємодія та взаємовплив графічно представлені на рис. 1.

Запропонована структурно-функціональна модель складається із п'яти основних взаємопов' язаних та взаємозалежних блоків. Перший, цільювий, блок включає соціальне замовлення сучасного суспільства на підготовку компетентного фахівця із міжнародного права, а також мету, що полягає у формуванні стратегічно компетентного юристаміжнародника. Для реалізації поставленої мети необхідно виконати наступні завдання: формування усвідомленого ціннісного ставлення до адекватного вибору стратегій як складової професійної компетентності юриста-міжнародника; системи професійних теоретичних знань, практичних вмінь і навичок; вибір змісту та методів формування стратегічних паттернів; активізація навчальної діяльності та підвищення рівня мотивації. У другому, методологічному блоці визначено компоненти стратегічної компетентності (змістовий, професійно-когнітивний, комунікативно-інформаційний, особистісно-мотиваційний та діяльнісно-операційний) та основні підходи, принципи (комунікативної спрямованості, активності, інтерактивності, практичної та ситуативної спрямованості) та правила. На підставі попереднього аналізу науково-педагогічних та нормативних джерел визначаємо як основні наступні педагогічні підходи: компетентісний, діяльнісний, особистісно-орієнтований, системний, мультидисцилінарний. Компетентнісний підхід передбачає проєктування (або перепроєктування) навчальних курсів на основі компетентностей, які студент повинен набути наприкінці навчання. Він відрізняеться від змістового підходу, котрий відштовхується від знань або дисциплін, які вважаються важдивими для навчадьного курсу або спеціалізації, та вкдюченні їх до навчальної програми. 


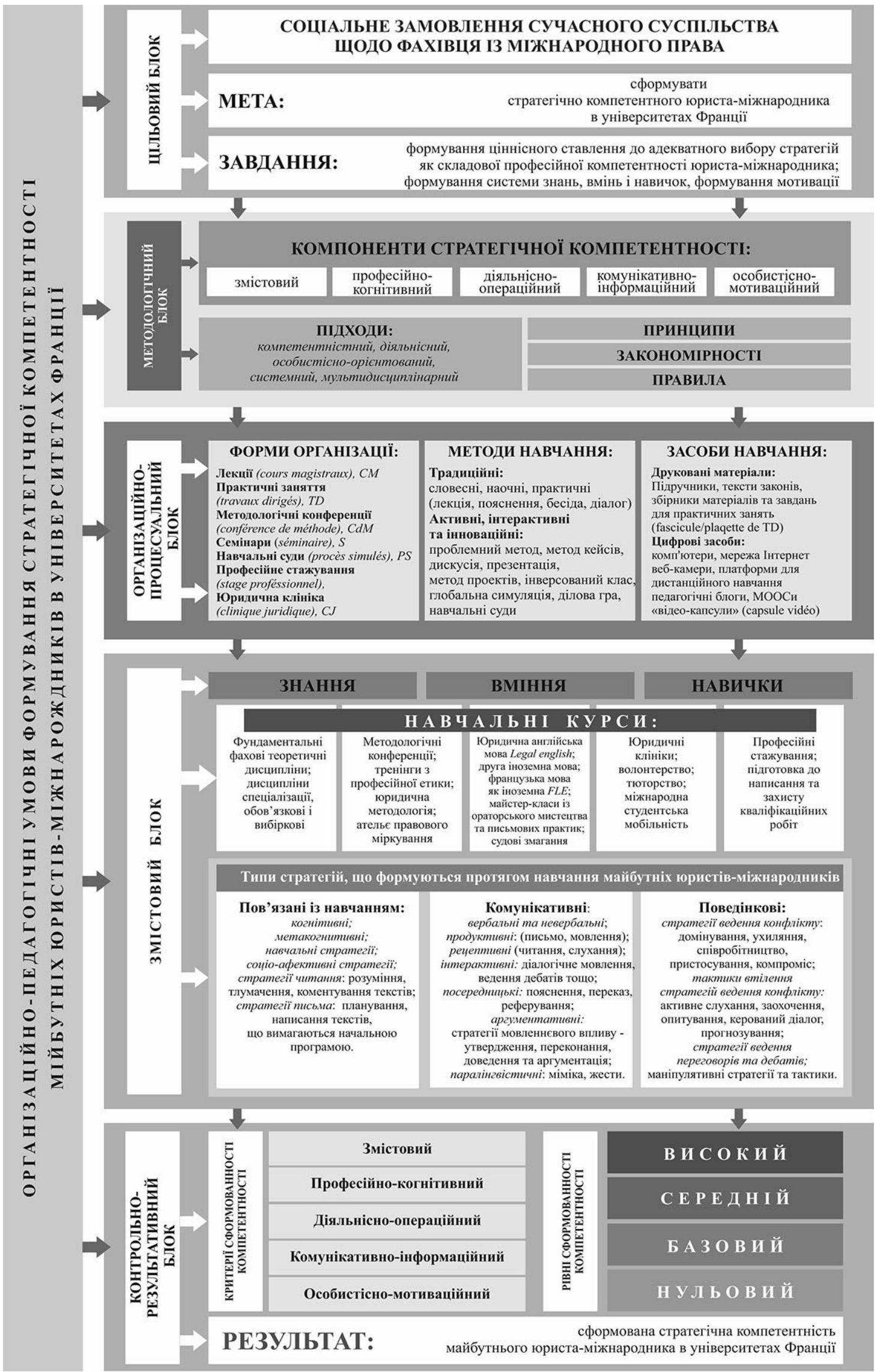

Рис. 1. Модель формування стратегічної компетентності майбутніх юристів-міжнародників в університетах Францііі 
У компетентністній перспективі, замість побудови освітніх програм, базуючись виключно на кількості годин конституційного, договірного права, європейського права тощо, необхідних для повного охоплення всього переліку знань програми, відбуваються дві зміни: по-перше, наперед визначається те, що випускник повинен мати у своєму багажі після завершення навчання на програмі; по-друге, цілі навчання визначаються не лише 3 точки зору змісту, а й з точки зору вмінь - що студент повинен уміти робити. Йдеться про те, що зміст не є єдиним важдивим виміром навчання. Кожен курс має чітко визначений предметний зміст, але акцент ставиться на те, які саме стратегії студенти повинні використовувати при роботі з поняттями, визначеннями, техніками тлумачення, нормами права, а також юридичним або доктринальним корпусом, які є предметом вивчення. Таким чином, даний підхід передбачає оцінку результатів навчання, якості процесу навчання у діяльнісному вимірі шляхом формування не тільки лише системи знань, умінь та навичок, а системи компетентностей, що включають також і особисті якості, цінності та переконання, психологічну підготовку, що відповідає меті нашого дослідження. Такий підхід заохочується на європейському рівні, оскільки він сприяе вільному пересуванню студентів та випускників, академічній мобільності. Змістовий підхід, як правило, створює численні перешкоди для вільного пересування, оскільки зміст навчання відрізняється в різних країнах, що унеможливлюе взаємне визнання та зарахування попереднього навчання або дипломів. Компетентністий підхід не усуває повністю випадки, коди дві освітні програми можуть не вважатися рівнозначними, але зменшуе їх кількість.

Особистісно-орієнтований та діяльнісний підходи також убачаються актуальним для нашого дослідження, оскільки процес формування стратегічної компетентності торкається комунікативного та навчадьного досвіду кожного студента. Отож, необхідно враховувати індивідуальні особливості, унікальність суб'єктивного досвіду студента, а також індивідуальні професійні потреби та майбутню професійну ситуацію, у якій буде реалізовуватися стратегічна компетентність майбутнього фахівця. Діяльнісний підхід в свою чергу передбачає спрямованість освітнього процесу на розвиток кдючових компетентностей і наскрізних умінь особистості, застосування теоретичних знань на практиці, формування здібностей до самоосвіти, успішну інтеграцію в соціум і професійну самореалізацію. Мультидисциилінарний підхід передбачає участь, співпрацю, злагоджену взаємодію, колективну роботу команд фахівців різних спеціальностей, колегіальне вироблення спільних підходів, необхідних у професійній діяльності у сфері міжнародного права.

Третій, орzанізацุійно-процесуальний блок містить форми організації (лекції, практичні заняття, методологічні конференції, семінари, навчальні суди, юридична кдініка), методи навчання (традиційні, активні, інтерактивні, інноваційні) та засоби навчання (друковані, цифрові тощо).

У процесі розробки четвертого, змістового блоку було проаналізовано зміст освітніх програм зі спеціальності «Міжнародне право». Аналіз засвідчуе, що основними видами професійної діяльності майбутніх юристів-міжнародників є: створення та аналіз міжнародних договорів, аналіз та застосування міжнародних нормативних документів (договорів, контрактів, резолюцій, опрацювання судових справ у міжнародних спорах (міждержавних, приватних або змішаних); підготовка документальної бази у судових справах, переклад міжнародних нормативних текстів або міжнародного судочинства, консультативна діяльність для французьких компаній із міжнародною діяльністю або іноземних компаній, що працюють у Франції; участь у переговорах та укладанні міжнародних нормативних документів; юридичний нагляд у сфері французьких, європейських та міжнародних нормативних актів [4]. Сучасні підходи до роботи у сфері міжнародного права передбачають як колективну (робота в групі, команді, складі комісії, проєктній групі, правозахисній організації тощо), так і індивідуальну діяльність (підготовка документальної бази у судових справах, опрацювання документів, us 
підготовка договорів, контрактів, робота із текстами законів, письмова перекладацька діяльність). Змістовий блок містить фундаментальні фахові дисципліни та дисциплін спеціалізації. На рівні «Бакалавр» (L1,2,3) відбувається загально юридична, теоретична підготовка та формуються фундаментальні юридичні знання із початком спеціалізації на 3-му році бакалаврату. На першому році магістратури (M1) відбувається початок спеціалізації у міжнародному та європейському праві завдяки вивченню наступних дисциплін: «Загальне міжнародне право: доктрини і методи», «Міжнародне приватне право», «Міжнародне публічне право», «Законодавство про конкуренцію Європейського Союзу», «Судочинство Європейського Союзу», «Зовнішня політика ЄС», «Міжнародне кримінальне право», «Міжнародне економічне право», «Арбітраж та альтернативне врегулювання суперечок», «Міжнародні договори», «Ділові контракти», «Застосування сили та право у збройних конфліктах», «Міжнародні переговори» тощо. Зміст навчання на другому році магістратури (М2) характеризується ще більш вузькою спеціалізацією завдяки поглибленому вивченню фундаментадьних дисципдін, таких як «Загальне міжнародне право», «Міжнародне публічне право», «Міжнародне приватне право» тощо, а також наступним дисциплінам спеціалізації: «Право міжнародних договорів», «ІІвестиційний арбітраж», «Погдиблене колізійне законодавство та право юрисдикцій», «Вирішення глобальних суперечок». Ознайомлення із методами, властивими юридичним наукам, їх подальше впровадження в роботу та опанування навичками професійної комунікації відбувається завдяки методологічним конференціям та дисциплінам, пов'язаним із вивченням іноземних мов, стратегій та тактик ведення переговорів та судових дебатів упродовж усього навчання.

Досліджуючи комунікації у контексті міжнародного права, І. Калитенко зазначає, що мовленнєва діяльність у сфері міжнародного права, як і в інших сферах, відбувається в усній та письмовій формі. Разом із тим у міжнародному праві існуе певний набір сталої лексики, що використовується у письмових (міжнародні договори, міжнародні конвенції, акти міжнародних організацій) та усних практиках. Акти взаємодії між державами здійснюються на основі міжнародно-правового звичаю, який виступає як доказ загальної практики, що визнається суб'єктами міжнародного права як правова норма, або ж на основі загальних принципів права, які розуміються учасниками міждержавних відносин як «основа основ», та текстів, до яких належать вищезгадані міжнародні договори, міжнародні конвенції, акти міжнародних організацій, тож спостерігається перетин усної та письмової форм комунікації [3, с. 170]. До переліку дисциплін, що сприяють формуванню комунікативно-інформаційної складової стратегічної компетентності, слід віднести такі: «Юридична ангдійська мова (Legal English)», «Англійська мова (за рівнями)», «Друга іноземна мова (німецька, іспанська, італійська, китайська, арабська, португальська, французька як іноземна FLE», «Практикум правового міркування», «Симуляція судового процесу 3 права Європейського Союзу», «Симуляція судового процесу 3 міжнародного права», «Симуляція судового процесу 3 права прав людини», «Симуляція переговорів», «Симуляції дипломатичної конференції», «Практичні заняття з іноземних мов», «Мовна лабораторія», «Написання контрактів», «Міжнародні переговори англійською та французькою мовами (глобальна симуляція)», «Ораторське мистецтво та мистецтво судових виступів», «Написання письмових повідомлень та інформаційних бюлетенів», «Business Game (англійською мовою)», «Навички усного висловлювання», «Підготовка до конкурсу промов (Grand oral)», «Підготовка до конкурсу письмових висловлювань (Grand ecrit)», «Договірні практики: практичні вправи з укладання договорів та ведення переговорів у цифровій сфері», «Укладання ділових контрактів: практичний підхід до договорів, аналіз випадків, консультації щодо укладання» [7-11]. Також змістовий блок запропонованої нами моделі містить типи стратегій, що формуються впродовж усього навчання майбутніх юристів-міжнародників (стратегії, пов'язані із навчальною діяльністю, поведінкові та комунікативні стратегіi)).

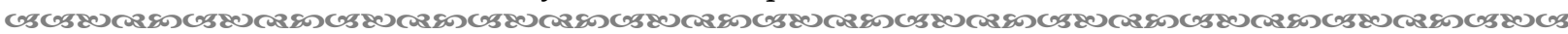
198 
П’ятим блоком запропонованої педагогічної моделі формування є контрольнорезультативний. У цьому блоці відповідно до попередньо визначених компонентів стратегічної компетентності майбутніх юристів-міжнародників визначено критерії (змістовий, професійно-когнітивний, діяльнісно-операційний, комунікативноінформаційний та особистісно-мотиваційний), показники та рівні сформованості аналізованої компетентності (високий, середній, базовий та нульовий). Сформована стратегічна компетентність майбутніх юристів-міжнародників $є$ результатом реалізації запропонованої моделі.

Висновки. Запропонована модель, розроблена на підставі теоретичного аналізу проблеми, досвіду підготовки фахівців із міжнародного права в університетах Франції, з урахуванням потреб суспільства та соціального замовлення на підготовку компетентних спеціалістів 3 міжнародного права, $\mathrm{e}$ ефективною і дієздатною. Французький досвід формування стратегічної компетентності майбутніх правників може бути адаптований до умов українських ВНЗ шляхом наступної розробки методичного забезпечення відповідних освітніх програм. Це може стати предметом подальшого наукового пошуку.

\section{Список використаних джерел:}

1. Базиль С. М. Авторська модель формування інформативної компетентності в майбутніх педагогів професійного навчання. Педагогічний альманах : збірник наукових праць / редкол. В. В. Кузьменко (голова) та ін. Херсон : КВНЗ «Херсонська академія неперервної освіти», 2020. Випуск 45. С. 76-83.

2. Гончаренко С. У. Педагогічні дослідження: методологічні поради молодим науковцям. Київ; Вінниця : ДОВ «Вінниця», 2008. 278 с.

3. Калитенко І. О. Трансформація мови комунікацій в контексті міжнародного права. Вісник Національного авіаційного університету. Серія: Філософія. Культурологія. 2019. Вип. 29. C. 170-175.

4. Національний реєстр професійних сертифікацій Франції «France Compétence» URL : https://www.francecompetences.fr

5. Словник-довідник з професійної педагогіки / за ред. А. В. Семенової. Одеса : Пальміра, 2006. $221 \mathrm{c}$.

6. Фіцула М. М. Педагогіка вищої школи : навчальний посібник для студентів вищих навчальних закладів. Київ : Центр учбової дітератури, 2009. 472 с.

7. Університет Версаль Сен-Кентен: веб-сайт. URL: http://www.uvsq.fr/welcome-to-uvsq406434.kjsp

8. Університет Екс-Марсель: веб-сайт. URL : https://www.univ-amu.fr/

9. Університет Париж 2 Пантеон-Асас: веб-сайm. URL : https://www.u-paris2.fr

10. Університет Париж I Пантеон-Сорбонна: веб-сайm. URL : https://www.pantheonsorbonne.fr

11. Університет Сержі-Понтуаз: веб-сайт. URL : https://www.u-cergy.fr

12. Schmidt-Lainé C., Pavé A. Environnement: modélisation et modèles pour comprendre agir ou décider dans un contexte interdisciplinaire. Natures Sciences Sociétés. Elsevier SAS. 2002. P. 5-25.

\section{References:}

1. Basyl, S. M. (2020). Avtorska model formuvannia informatyvnoi kompetentnosti v maibutnikh pedahohiv profesiinoho navchannia [The author's model of the formation of future professional training teachers' informative competence]. Pedahohichnyi almanakh, 45, 76-83 [in Ukrainian].

2. Honcharenko, S. U. (2008). Pedahohichni doslidzhennia: metodolohichni porady molodym naukovtsiam [Pedagogical research: methodological advice for young scientists]. Kyiv - Vinnytsia: DOV "Vinnytsia" [in Ukrainian].

3. Kalytenko, I. O. (2019). Transformatsiia movy komunikatsii v konteksti mizhnarodnoho prava [Transformation of speech communication in the context of international law]. Visnyk Natsionalnoho aviatsiinoho universytetu. Seriia: Filosofiia. Kulturolohiia, 29, 170-175 [in Ukrainian].

4. National Register of Professional Certifications of France. (2020). Site oficiel de "France Compétence" [Official site of National Register of Professional Certifications of France]. Retrieved from http://www.francecompetences.fr/ [in French]. 
5. Semenova, A. V. (Ed.) (2006). Slovnyk-dovidnyk z profesiinoi pedahohiky [Dictionary-reference book on professional pedagogy]. Odesa: Palmira [in Ukrainian].

6. Fitsula, M. M. (2009). Pedahohika vyshchoi shkoly: navchalnyi posibnyk dlia studentiv vyshchykh navchalnykh zakladiv [Higher school pedagogy: a textbook for students of higher educational institutions]. Kyiv: Tsentr uchbovoi literatury [in Ukrainian].

7. Université de Versailles Saint-Quentin-en-Yvelines. (2020). Site oficiel de l'université VersaillesSaint-Quentin-en-Yvelines [Official site of Versailles-Saint-Quentin-en-Yvelines University]. Retrieved from http://www.uvsq.fr/ [in French].

8. Université Aix-Marseille. (2020). Site oficiel de l'université Aix-Marseille [Official site of AixMarseille University]. Retrieved from http:// https://www.univ-amu.fr/ [in French].

9. 9.Université Paris 2, Panthéon-Assas. (2020). Site oficiel de Paris 2 Panthéon-Assas [Official site of Paris 2, Pantheon-Assas University]. Retrieved from http:// https://www.u-paris2.fr/ [in French].

10. 10.Université Paris 1, Panthéon-Sorbonne. (2020). Site oficiel de l'université Paris 1, PanthéonSorbonne [Official site of Paris 1, Pantheon-Sorbonne University]. Retrieved from http:// https://www.pantheonsorbonne.fr/ [in French].

11. 11.Université Cergy-Pontoise. (2020). Site oficiel de l'université Cergy-Pontoise [Official site of Cergy-Pontoise University]. Retrieved from http:// https://www.u-cergy.fr/ [in French].

12. Schmidt-Lainé, C., \& Pavé, A. (2002). Environnement: modélisation et modèles pour comprendre agir ou décider dans un contexte interdisciplinaire [Environment: modeling and models for understanding the action or decision in the interdisciplinary context]. Natures Sciences Sociétés, 5-25 [in French].

\section{THE MODEL OF FORMATION OF STRATEGIC COMPETENCE OF FUTURE INTERNATIONAL LAWYERS IN THE UNIVERSITIES OF FRANCE}

Pysarevska O. V., orcid.org/0000-0001-5166-1464

The article sets to analyze current approaches to modelling as a research method of pedagogical processes and phenomena that allow detecting their main components and describe their interrelation and conditions of functioning. The notion of strategic competence of a future international lawyer is considered and understood within the framework of our research as a complex, dynamic and integrative system of personal qualities and professionally relevant expertise, skills and abilities aimed at an adequate and effective choice of strategies and tactics in professional activities acquired by students during professional training. The research results of the formation process of strategic competence of future experts in the field of international law by the example of student's of international law training at the universities of France in the form of an original formation model of the mentioned competence are presented in the article. The analysis results of scientific and pedagogical sources and regulatory documents allowed distinguishing five main interrelated blocks of the designed model: purpose-oriented containing the social demand of the society, aim and task of strategic competence formation; methodological including its components, basic principles and approaches to its formation (competence-based, systemic, activity, transverse); organizational and procedural containing forms, methods, means of forming the analyzed competence; content-based, i.e. the content of academic subjects, curriculum, knowledge, expertise, skills; control- and result-based, i.e. the criteria, indicators and levels of the well-formedness of the strategic competence of future international lawyers during their professional training at the universities of France.

Key words: strategic competence, modelling, model, international law, higher education of France. 